\title{
Parametry sprężyste łupków zawierających materię organiczną określone na podstawie teoretycznych relacji Biota-Gassmana i Kustera-Toksöza
}

\begin{abstract}
Wykonano próby obliczania parametrów sprężystych dla łupków ilastych, będących potencjalnymi skałami macierzystymi dla węglowodorów. Wykorzystano w tym celu znane modele teoretyczne Biota-Gassmana i Kustera-Toksöza oraz autorski program Estymacja-TP. Przeprowadzono wstępną analizę wartości parametrów szkieletowych niezbędnych do obliczeń. Analiza została oparta na danych literaturowych oraz na pracach autorki. Zmiany parametrów sprężystych skał macierzystych, jak również ich wzajemne relacje dostarczają ważnych informacji o wielkościach generowanych węglowodorów i charakterystykach geomechanicznych skał, określanych na podstawie profilowań akustycznych i pomiarów sejsmicznych. Modele syntetyczne skał ilastych zawierają uśrednione wielkości charakterystyczne dla łupków gazonośnych Barnett Shale w Teksasie, łupków Green River w Colorado oraz łupków syluru i ordowiku z basenu bałtyckiego.
\end{abstract}

Słowa kluczowe: łupki gazonośne, sylur, ordowik, modele Biota-Gassmana, Kustera-Toksöza, program Estymacja-TP.

\section{Determination of elastic parameters of organic shales specified on the basis of theoretical relationships of Biot-Gassmann and Kuster-Toksöz}

\begin{abstract}
Tests were carried out for calculating the elastic parameters for shales, which are potential hydrocarbons source rocks. For this purpose the Biot-Gassmann and Kuster-Tosköz theoretical models and original program ESTYMACJA TP were used. A preliminary analysis of the values of the matrix of the rocks were made, which are necessary for the calculations. The analysis were based on literature data and recent works by the author. Changes in elastic parameters of source rock and their relationships provide important information about the volumes of the generated hydrocarbons and geotechnical characteristics of rocks, determined on the basis of acoustic logs and seismic measurements. The developed synthetic shale rock models contain averaged values characteristic for the organic-rich Barnett Shale in Texas, Green River shale in Colorado and Silurian, and Ordovician shales of the Baltic Basin.
\end{abstract}

Key words: gas shale, Ordovician, Silurian, Biot-Gassmann model, Kuster-Tosköz model, ESTYMACJA TP program.

\section{Wprowadzenie}

Łupki ilaste charakteryzujące się dużą dojrzałością termiczną, zawierające substancję organiczną TOC powyżej 2\% (wagowo) mogą stanowić skałę macierzystą dla węglowodorów [18]. Charakteryzują się one podwyższoną zawartością materii organicznej oraz na ogół wyższą naturalną promieniotwórczością gamma, co często wiąże się z wyższą zawartością węgla organicznego. Mają ekstremalnie małą porowatość i bardzo niską przepuszczalność [23].

Mechanizm magazynowania gazu w łupkach jest złożony. Większość gazu wypełnia naturalną sieć szczelin oraz pory, a charakter przepływu gazu może być opisany prawem Darcy'ego w odniesieniu do mezo- i makroporów (identyczny jak w przypadku konwencjonalnych złóż porowatych). Pewna część gazu pozostaje zaadsorbowana w postaci warstw molekuł na powierzchni materii organicznej i uwalniana w miarę spadku ciśnienia złożowego. Przepływ gazu w nano- i mikroporach skały można opisać równaniem dyfuzji Knudsena [16].

Minerały ilaste, będące ważnymi składnikami łupków, wpływają na ich własności sprężyste i anizotropię. Odmienne 
właściwości anizotropowe minerałów ilastych powodują zróżnicowanie ich parametrów sprężystych $[3,15]$. Parametry sprężyste łupków ilastych zależą m.in. od ich składu mineralnego, udziału poszczególnych frakcji, a także od kształtów i orientacji ziaren. Jones i Wang [14], na przykładzie próbek łupków kredowych z basenu Williston (Północna Dakota), zaprezentowali eksperymentalne pomiary pięciu niezależnych składowych tensora sprężystości: $\mathrm{C}_{11}, \mathrm{C}_{33}, \mathrm{C}_{44}, \mathrm{C}_{66} \mathrm{i} \mathrm{C}_{13}$, charakteryzujących najprostszy przypadek anizotropii o symetrii heksagonalnej, tzw. słabej anizotropii (TI - transverse isotropy) [27].

Jeśli fale propagują wzdłuż płaszczyzny $X Y$, równolegle do warstwowania, prędkość fali podłużnej w skałach ilastych $\left(V_{P s h}\right)$ jest wyrażona za pomocą składowej $\mathrm{C}_{11}$ i gęstości łupków $\left(\rho_{s h}\right)$; prędkość fali poprzecznej, spolaryzowanej w kierunku uwarstwienia $\left(V_{S H s h}\right)$ zawiera składową $\mathrm{C}_{66}$, a prędkość fali poprzecznej spolaryzowanej prostopadle do warstwowania $\left(V_{S V s h}\right)$ - składową $\mathrm{C}_{44}[15]$.

$$
V_{P_{s h}}=\sqrt{\frac{C_{11}}{\rho_{s h}}} \quad V_{S H s h}=\sqrt{\frac{C_{66}}{\rho_{s h}}} \quad V_{S V s h}=\sqrt{\frac{C_{44}}{\rho_{s h}}}
$$

Dla fal propagujących wzdłuż osi $Z$ prędkości fal podłużnych $V_{P s h}$ i poprzecznych $V_{S H s h}$ wyrażone są poprzez składowe $\mathrm{C}_{33} \mathrm{i} \mathrm{C}_{44}$, zaś dla propagacji pod kątem $45^{\circ}$ do osi $Z$ prędkość fali P zawiera kombinacje wszystkich pięciu składowych tensora sprężystości.

Podstawiając składowe tensora do wzorów na prędkości fal P i S oraz uwzględniając średnią gęstość objętościową dla łupków ilastych $\rho_{s h}=2,65 \mathrm{~g} / \mathrm{cm}^{3}$, uzyskuje się bardzo różne wartości, w zależności od tego, z jakiej składowej sprężystej zostaną określone prędkości, a w związku z tym stosunek $V_{P} / V_{S}$ może się zmieniać od 1,79 aż do 2,5, co pociąga zmianę współczynnika Poissona $v$ od 0,28 do 0,4 [3].

Parametry sprężyste minerałów ilastych znacznie różnią się od iłów w warunkach in situ.

Katahara [15] podaje wartości prędkości dla izotropowych kryształów illitu, chlorytu i kaolinitu. Prędkości te są dość wysokie i wynoszą:

- dla illitu $V_{P}=5,82 \mathrm{~km} / \mathrm{s}$ i $V_{S}=3,37 \mathrm{~km} / \mathrm{s}$,

- dla chlorytu $V_{P}=5,93 \mathrm{~km} / \mathrm{s}$ i $V_{S}=3,35 \mathrm{~km} / \mathrm{s}$,

- dla kaolinitu $V_{P}=6,23 \mathrm{~km} / \mathrm{s}$ i $V_{S}=3,55 \mathrm{~km} / \mathrm{s}$.

W kilku publikacjach prędkości w iłach są estymowane na podstawie empirycznych zależności pomiędzy prędkościami i porowatością oraz zaileniem, otrzymanymi z profilowań geofizyki otworowej lub z danych laboratoryjnych. Np. Castagna et al. [9], stosując dane z profilowań dla piaskowców formacji Frio, ekstrapolują prędkości w iłach będących mieszaniną montmoryllonitu i illitu, uzyskując: $V_{P s h}=3,60 \mathrm{~km} / \mathrm{s}$ i $V_{S s h}=1,85 \mathrm{~km} / \mathrm{s}$ oraz $V_{P} / V_{S}=1,95$.

Podobne wartości, $V_{P s h}=3,41 \mathrm{~km} / \mathrm{s}$ i $V_{S s h}=1,63 \mathrm{~km} / \mathrm{s}$, dla mieszaniny iłów uzyskali Han et al. [13] z danych laboratoryjnych. W pracy M. Bały [3], przy modelowaniach parametrów sprężystych dla skał mioceńskich z wykorzystaniem relacji Biota-Gassmana i Kustera-Toksöza, wprowadzono dla łupków $V_{P s h}=3,175 \mathrm{~km} / \mathrm{s}, V_{S s h}=1,65 \mathrm{~km} / \mathrm{s}$ oraz gęstość objętościową $=2,6 \mathrm{~g} / \mathrm{cm}^{3}$. Są to wartości znacznie niższe niż znalezione przez Katahara [15] dla kryształów ilastych.

W innych pracach podano wyniki dla sztucznie tworzonych agregatów typu ił-woda. Np. Allen et al. [1] uzyskali dla smektytu: $V_{P}=2,3 \mathrm{~km} / \mathrm{s}, V_{S}=1,3 \mathrm{~km} / \mathrm{s}$ i gęstość objętościową $=2,29 \mathrm{~g} / \mathrm{cm}^{3}$. Dla kaolinitu: $V_{P}=2,78 \mathrm{~km} / \mathrm{s}$, $V_{S}=1,52 \mathrm{~km} / \mathrm{s}$ oraz gęstość $2,59 \mathrm{~g} / \mathrm{cm}^{3}$. Ostatnie wyniki są zgodne z podanymi przez Prasad et al. [24] wynikami badań przy zastosowaniu mikroskopu elektronowego AFAM (atomic force acoustic microscopy).

\section{Skład mineralny gazonośnych łupków kambru, syluru i ordowiku basenu bałtyckiego}

Analizując szczegółowo dostępny materiał literaturowy $[20,21]$, można zauważyć, że w otworach wierconych na zlecenie Państwowego Instytutu Geologicznego - Państwowego Instytutu Badawczego w osadach landoweru basenu bałtyckiego występują głównie iłowce oraz czarne łupki smoliste i bitumiczne, nierzadko z przewarstwieniami wapiennymi, wyraźnie spękanymi. W utworach tych stwierdzono występowanie dużej ilości graptolitów. W utworach wenloku przeważają iłowce, miejscami wapniste, łupkowate, z licznym detrytusem i ze skupieniami pirytu, najczęściej laminowane, również z licznymi graptolitami. Osady ludlowu są wykształcone jako iłowce i mułowce, miejscami wapniste albo z przewarstwieniami wapienia, z muskowitem, z nielicznymi graptolitami.

Utwory ordowiku to przeważnie iłowce wapniste, zwięzłe, o silnym zapachu bitumicznym, z soczewkami ciemnoszarych margli oraz wkładkami czarnych piaskowców ilastych [21]. Jako wskaźnik zwiększonej substancji macierzystej w skale można traktować anomalnie wysokie zawartości $U$ i obniżone $\rho_{b}$ obserwowane na profilowaniach spektrometrycznych gamma i gamma-gamma.

Opierając się na wynikach badań materii organicznej w otworze D-IG1 (wg Grotek, w: [20]), można stwierdzić, że ,[...] stopień jej przeobrażenia wzrasta z wiekiem skał oraz z głębokością pogrążenia osadów i odpowiada (w utworach kambru środkowego, ordowiku i syluru) późnej fazie generowania ropy naftowej z możliwością generowania gazów mokrych i kondensatów".

Podobne stwierdzenia zawarte są w pracy Grotek (w: [21]) pt. Charakterystyka petrograficzna oraz dojrzałość termiczna rozproszonej materii organicznej odnośnie do otworu Słupsk-IG1. 
Tablica 1. Uśredniona zawartość węgla organicznego na podstawie badań laboratoryjnych wykonanych w utworach: syluru, ordowiku i kambru z otworu D-IG1

\begin{tabular}{|c|c|c|c|c|c|c|}
\hline \multirow{2}{*}{$\begin{array}{l}\text { Interwał pobrania prób } \\
\qquad[\mathrm{m}]\end{array}$} & \multirow{2}{*}{ Stratygrafia } & \multirow{2}{*}{ Litologia } & \multicolumn{3}{|c|}{ Zawartość Corg [\%] } & \multirow{2}{*}{$\begin{array}{l}\text { Liczba } \\
\text { danych }\end{array}$} \\
\hline & & & średnia & minimum & maksimum & \\
\hline $1075,0 \div 1563,5$ & sylur, przydol & iłowce & 0,37 & 0,10 & 0,70 & 19 \\
\hline \multirow{2}{*}{$1619,5 \div 2719,4$} & \multirow{2}{*}{ sylur, ludlow } & iłowce & 0,52 & 0,42 & 0,90 & 11 \\
\hline & & mułowce & 0,30 & 0,30 & 0,30 & 2 \\
\hline $2795,3 \div 2877,5$ & sylur, wenlok & iłowce & 0,90 & 0,73 & 1,04 & 4 \\
\hline $2912,6 \div 2933,0$ & sylur, landower & iłowce & 1,61 & 0,13 & 6,10 & 5 \\
\hline $2942,0 \div 2973,0$ & ordowik, kat, sandb & iłowce & 1,33 & 0,30 & 3,10 & 7 \\
\hline $2997,5 \div 3003,0$ & ordowik, flo & iłowce & 0,27 & 0,20 & 0,30 & 3 \\
\hline \multirow{2}{*}{$3017,0 \div 3264,9$} & \multirow{2}{*}{ kambr środkowy } & iłowce & 0,83 & 0,20 & 3,60 & 12 \\
\hline & & piaskowce i mułowce & 0,35 & 0,10 & 0,60 & 13 \\
\hline \multirow{3}{*}{$3383,3 \div 3509,0$} & \multirow{3}{*}{ kambr dolny } & iłowce & 0,50 & 0,20 & 0,70 & 3 \\
\hline & & mułowce & 0,29 & 0,10 & 0,60 & 8 \\
\hline & & piaskowce & 0,17 & 0,20 & 0,50 & 14 \\
\hline
\end{tabular}

W tablicy 1 przedstawiono uśrednione dane dotyczące zawartości węgla organicznego (TOC) opracowane na podstawie badań laboratoryjnych z otworu D-IG1 (Klimuszko, w: [20]).

Wykorzystując powyższe informacje oraz dane geofizyki otworowej z lat 1972-1975, udostępnione w ramach prac realizowanych na zlecenie Instytutu Nauk Geologicznych PAN w Warszawie [5], przeprowadzono najpierw korektę profilowań na wpływ środowiska (environmental correction) i kali- brację krzywych radiometrycznych (z jednostek imp./min na jednostki API) oraz wykonano interpretację kompleksową i obliczono czasy interwałowe fal podłużnych i poprzecznych, ich prędkości $V_{P}$ i $V_{S}$, stosunki $V_{P} / V_{S}$, jak również gęstości objętościowe dla utworów wenloku, ordowiku i kambru dolnego.

Na rysunku 1 przedstawiono, dla przykładu, wyinterpretowane parametry sprężyste, przy zastosowaniu programu Estymacja TP i modelu Kustera-Toksöza w otworze D-IG1.

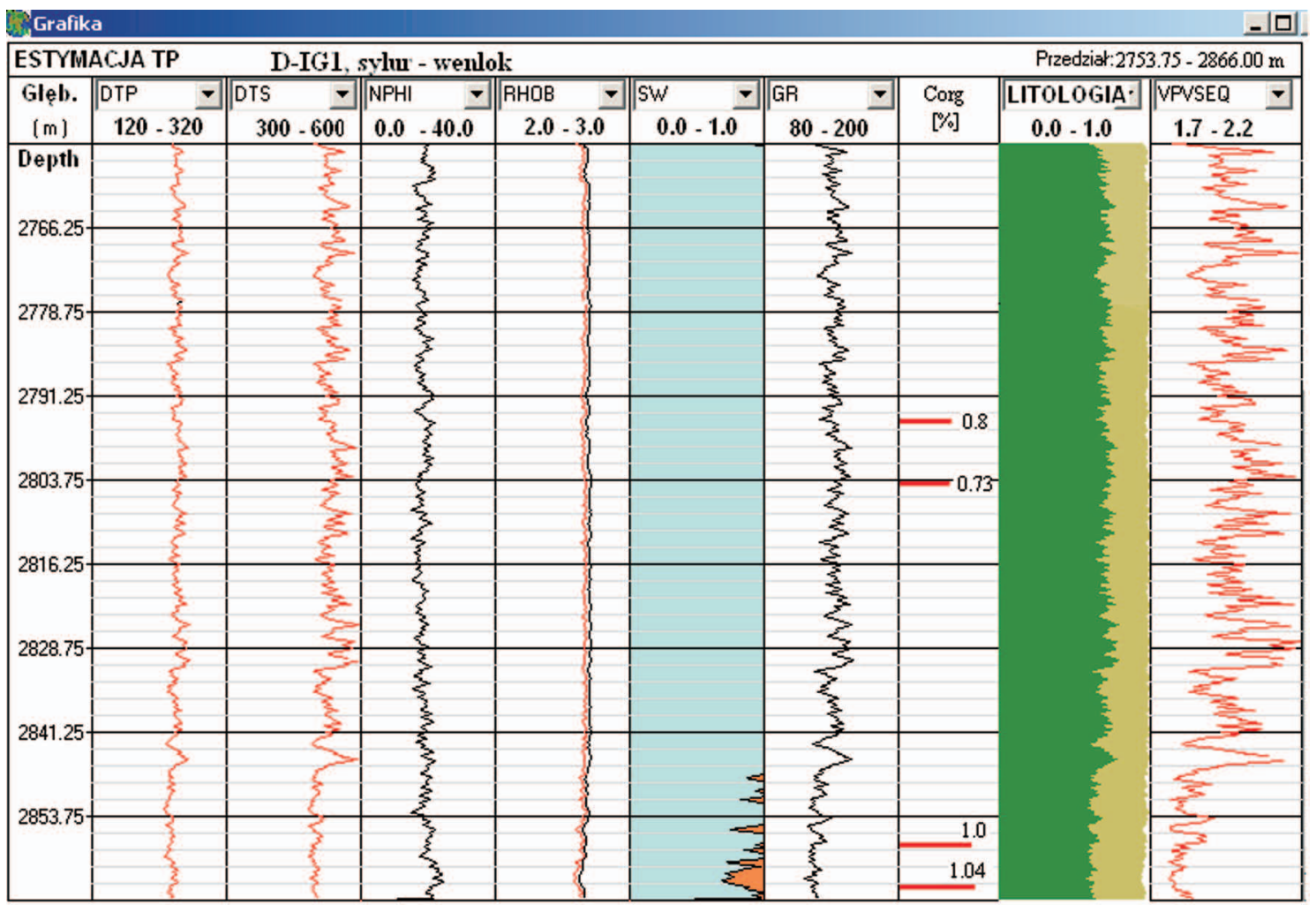

Rys. 1. Fragmenty krzywych prezentują obliczone parametry: czasów interwałowych fal P - DTP i S - DTS w $\mu \mathrm{s} / \mathrm{m}$

(ścieżka 1 i 2), gęstości objętościowych RHOB $\left(\mathrm{g} / \mathrm{cm}^{3}\right)$ (ścieżka 4) oraz $V_{P} / V_{S}$ (ścieżka 8). Uproszczona litologia oznaczona kolorami: ciemnozielony - illity, jasnozielony - smektyty, porowatość - biały 
Interwał $2753,75 \div 2866,00$ m odpowiada utworom ilastym wenloku. Przy modelowaniach założono (na podstawie: Wyniki badań litologicznych, stratygraficznych, sedymentologicznych, petrograficznych i geochemicznych, w: [20]) obecność minerałów ilastych: illitu, illitu/smektytu lub illitu/chlorytu o parametrach szkieletowych podanych w tablicy 2. Przy doborze parametrów kierowano się głębokością występowania utworów oraz stwierdzonymi domieszkami innych minerałów (w niewielkich ilościach), takich jak: kwarc, węglany, skalenie oraz piryt.

Na rysunku 1 kolorem czerwonym zaznaczono obliczone krzywe, a czarnym pomierzone w otworze. Na ścieżkach 1 i 2 przedstawiono czasy interwałowe fal P (DTP) i S (DTS) $\mathrm{w} \mu \mathrm{s} / \mathrm{m}$, na kolejnej (ścieżka 3) zarejestrowaną krzywą porowatości neutronowej (\% w skali wapienia), na ścieżce 4 gęstość objętościową RHOB w g/ $\mathrm{cm}^{3}$, na ścieżkach 5 i 6 wybrane krzywe SW (nasycenie wodą) i profilowanie gamma (w API), a na następnej zaznaczono uproszczony profil litologiczny (kolor ciemnozielony - illity, jasnozielony - smektyty, biały - porowatość). W łupkach ilastych wenloku obserwuje się bardzo wysokie wartości promieniowania gamma; średnia wartość 150 API, a w odcinku dolnym landoweru 2925,0 2933,5 m jeszcze wyższe: 325 API. Prędkości średnie fali P wynoszą $V_{P s r}=4,26 \mathrm{~km} / \mathrm{s}$, fali S $V_{S s r}=2,27 \mathrm{~km} / \mathrm{s}$, a stosunek $V_{P} / V_{S}$ zawiera się między 1,87 a 1,98 . W tych interwałach porowatości wahają się w przedziale od 0,01 do 0,05 , lokalnie spadają poniżej 0,01 . Na rysunku 1 zaznaczono (na ścieżce 7) zawartość węgla organicznego Corg ([\%]), oznaczoną laboratoryjnie (Klimuszko w: Modliński (red.), 2011). W utworach łupkowo-ilastych ordowiku wartości parametrów kształtują się podobnie (rysunek 2).

W kambrze następuje zasadnicza zmiana litologii. W górnym kambrze pojawiają się osady wapieni, margli zailonych i iłowców, a w środkowym i dolnym występują piaskowce, iłowce i mułowce. Wyniki obliczonych i pomierzonych profilowań w odcinku kambru dolnego pokazują strefy piaskowcowe nasycone węglowodorami. Można zauważyć duże wahania prędkości $V_{P}$ i $V_{S}$ oraz stosunku $V_{P} / V_{S}$, odzwierciedlające zmiany litologii i nasycenia węglowodorami.

\section{Modelowanie parametrów sprężystych w łupkach ilastych zawierających materię organiczną}

Opracowano syntetyczny model dla łupków ilastych zawierających materię organiczną, na podstawie danych literaturowych $[1,3,22]$.

W pracy M. Bały [3] przedstawiono wyniki obliczeń wpływu obecności materiału ilastego na prędkości propagacji fal P i S. Zastosowano teoretyczne modele ośrodków porowatych. Wykorzystano w tym celu zmodyfikowany model Biota-Gassmana oraz Kustera-Toksöza. Szczegółowe opisy modeli można znaleźć w publikacji [6].

Na rysunku 3a zaprezentowano zależności $V_{P}$ i $V_{S}$ w funkcji objętościowej zawartości frakcji ilastej $V_{\text {sh }}$, obliczone przy użyciu modelu Biota-Gassmana. Przy obliczeniach założono, że porowatość $(\Phi)$ modelu zmienia się od 0,05 do 0,25 , a objętości frakcji ilastej zmieniają się w przedziale

Tablica 2. Parametry szkieletowe minerałów ilastych użytych przy obliczeniach

\begin{tabular}{|c|c|c|c|c|}
\hline Stratygrafia & Minerały ilaste & $K[\mathrm{GPa}]$ & $\mu[\mathrm{GPa}]$ & $\rho\left[\mathrm{g} / \mathrm{cm}^{3}\right]$ \\
\hline \multirow{2}{*}{ Sylur, wenlok } & illit/smektyt + domieszki & 26 & 14 & 2,65 \\
\cline { 2 - 5 } & illit/chloryt + domieszki & 37 & 22 & 2,72 \\
\hline \multirow{2}{*}{ Sylur, landower } & illit + domieszki & 27 & 16 & 2,65 \\
\cline { 2 - 5 } & illit/smektyt + domieszki & 38 & 25 & 2,72 \\
\hline \multirow{3}{*}{ Ordowik } & illit & 27 & 16 & 2,69 \\
& illit/smektyt + domieszki & 38 & 25 & 2,70 \\
\cline { 2 - 5 } & $\begin{array}{c}\text { illit/chloryt } \\
\text { chloryt + domieszki }\end{array}$ & 44 & 21 & 2,72 \\
\hline
\end{tabular}

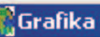

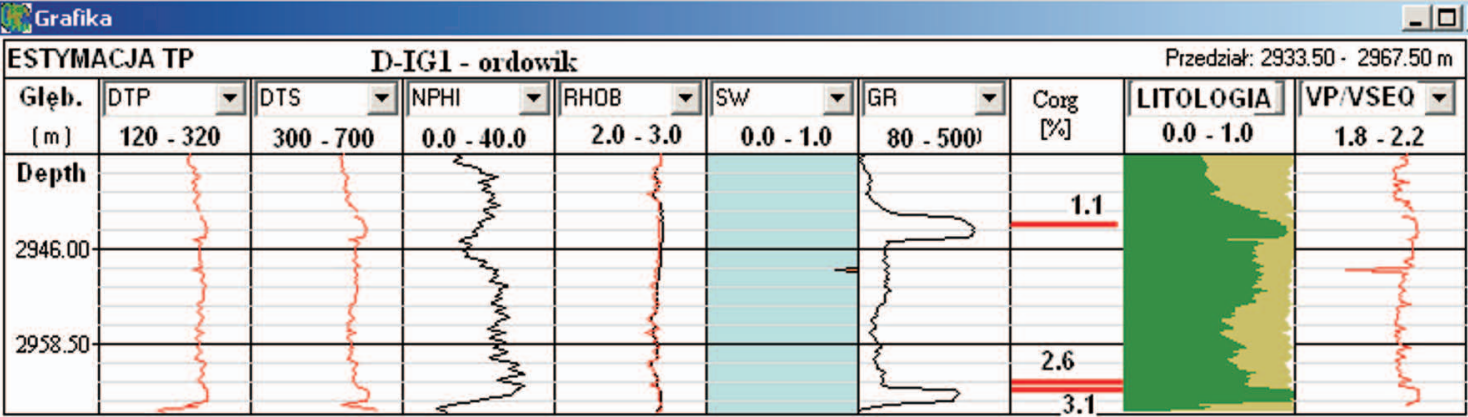

Rys. 2. Obliczone parametry sprężyste dla łupków ilastych ordowiku 
od 0,0 do 0,8 . Założono też strukturalny typ zailenia. Przyjęto następujące parametry szkieletowe: dla piaskowca: $\rho_{m a}=2,65 \times 10^{3} \mathrm{~kg} / \mathrm{m}^{3} ; K_{m a}=35,45 \mathrm{GPa} ; \mu_{m a}=39,81 \mathrm{GPa}$; $D T P_{m a}=161 \mu \mathrm{s} / \mathrm{m}$; dla iłu: $\rho_{s h}=2,60 \times 10^{3} \mathrm{~kg} / \mathrm{m}^{3}$; $K_{s h}=16,83 \mathrm{GPa} ; \mu_{s h}=7,04 \mathrm{GPa} ; D T P_{s h}=330 \mu \mathrm{s} / \mathrm{m}$; dla wody nasycającej (solanki): $\rho_{w}=1,03 \times 10^{3} \mathrm{~kg} / \mathrm{m}^{3} ; K_{w}=2,638 \mathrm{GPa}$; $\mu_{s h}=0,0 \mathrm{GPa} ; D T P_{w}=600 \mu \mathrm{s} / \mathrm{m}$ (gdzie: $\rho$ - gęstość objętościowa, $K$ - moduł odkształcenia objętości, $\mu$ - moduł odkształcenia postaci, DTP - czas interwałowy przebiegu fali P).

Przyjmując powyższe wartości stałych szkieletowych, uwzględniano również sugestie i wyniki prac prezentowanych i publikowanych w materiałach konferencji Geopetrol $2004[10,25,26]$. Analiza wyników obliczeń pokazuje, że można zauważyć regularny spadek wartości prędkości $V_{P}$ i $V_{S}$ w miarę wzrostu objętości frakcji ilastej, a tym samym obniżania się objętości składnika piaskowcowego [3]. Stosunek obu prędkości $\left(V_{P} / V_{S}\right)$ wzrasta wraz ze wzrostem zailenia i w zależności od współczynnika porowatości oscyluje między 1,65 (przy braku zailenia) a 2,3 (dla dużej zawartości frakcji ilastej).

W pracy Zhu F. i in. [31] przedstawiono podobne wnioski; zmiany $V_{P} / V_{S}$ mają wzrost liniowy - od 1,6 dla „czystych” piaskowców, aż do 2,1 dla „czystych” iłów. Autorzy wprowadzają też pojęcie tzw. krytycznej zawartości iłów. Gdy zawartość iłów jest większa od krytycznej ( $40 \%)$, parametry sprężyste mieszaniny piaskowca i iłu zmieniają się zgodnie z teoretycznymi obliczeniami. Gdy zawartość iłów jest mniejsza od krytycznej, następuje niewielki wzrost $V_{P}$ i $V_{S}$ wraz ze wzrostem zawartości frakcji ilastej.

$\mathrm{Na}$ rysunku $3 \mathrm{~b}$ zaprezentowano wpływ zailenia na prędkość fal P i S, obliczony według modelu Kustera-Toksöza. Założono, że frakcja ilasta występuje: A) w szkielecie skalnym (krzywe czarne) lub B) w porach wydłużonych o niskich współczynnikach kształtu $\alpha_{s h}=0,05$ ( $\alpha$ oznacza stosunek półosi mniejszej do większej w porach o kształcie elipsoidalnym), podczas gdy woda złożowa wypełnia pory o większych współczynnikach kształtu $\alpha_{p o r}=0,1$, a $\Phi=C\left(\alpha_{p o r}\right)=0,1$ (krzywe amarantowe). Pozostałe parametry szkieletowe są takie same jak w poprzednich obliczeniach. Zmiany wywołane obecnością iłów są zdecydowanie większe w wariancie (B), gdy ił znajduje się w porach skały (rysunek 3b). Przyjmując założenia wariantu (A), otrzymano znacznie niższe wartości $V_{P}$ i $V_{S}$ niż posługując się modelem BG. Zakładając inne parametry modelu, uzyskamy nieco odmienne wartości liczbowe, ale tendencja zmian zostanie zachowana.

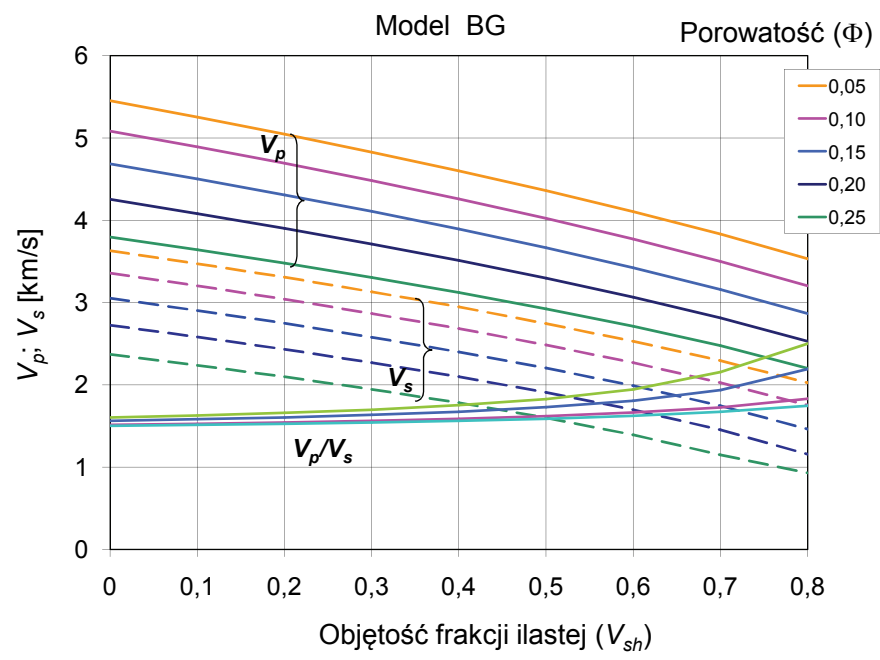

Rys. 3a. Wpływ $V_{s h}$ na prędkość fali podłużnej i poprzecznej, przy zadanych współczynnikach porowatości (parametr krzywych). Obliczenia wykonano, wykorzystując model Biota-Gassmana ( $V_{P}-$ krzywe ciągłe, $V_{S}-$ krzywe przerywane)

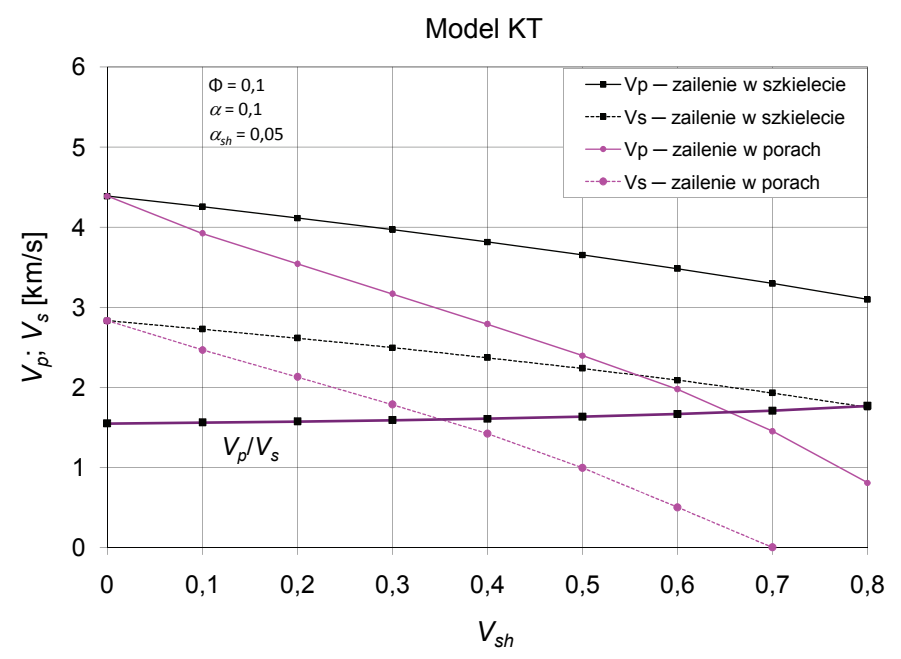

Rys. 3b. Wpływ $V_{s h}$ na prędkość fal P i S. Obliczenia wykonano przy użyciu modelu Kustera-Toksöza. Założono, że A) frakcja ilasta występuje w szkielecie (krzywe ciągłe);

B) frakcja ilasta występuje w porach o współczynniku kształtu $\alpha_{\mathrm{sh}}=0,05$ (krzywe przerywane). Zaznaczono również krzywą $V_{P} / V_{S}$ obliczoną dla wariantu (A)

Wzrost stosunku $V_{P} / V_{S}$ ze wzrostem zailenia (do około 1,97 przy całkowitym zaileniu) pociąga za sobą także odpowiedni wzrost współczynnika Poissona $v$.

Jednak wartości $V_{P} / V_{S}$ dla różnych minerałów ilastych mogą się znacząco różnić, ze względu na obserwowaną w nich anizotropię [15].

\section{Model syntetyczny łupków ilastych - omówienie wyników modelowań}

Modelowania parametrów sprężystych i gęstości objętościowych dokonano przy użyciu teoretycznych relacji Kustera i Toksöza [17] z zastosowaniem rozszerzenia DEM (differential effective medium). Uogólnienie modelu przy 
wykorzystaniu metody self-consistent przedstawili w swoich pracach Berryman et al. [8] oraz Xu i White [29], stosując differential effective medium (DEM).

Obliczenia przeprowadzono dla syntetycznych modeli łupków ilastych z uwzględnieniem obecności materii organicznej w szkielecie skalnym lub w przestrzeni porowej wraz z obecnością wody i węglowodorów gazowych w porach skał.

Passey w pracy [22] proponuje następujący model skał zawierających lub nie materię organiczną, dzieląc je na trzy składniki:

1) szkielet skalny,

2) stała materia organiczna,

3) medium wypełniające pory.

Skały niezawierające materii organicznej złożone są z dwóch składników: szkieletu i wody wypełniającej pory (rysunek 4a).

W „niedojrzałych skałach” materia organiczna i szkielet tworzą część stałą, a woda wypełnia pory (rysunek 4b).

W „dojrzałych skałach źródłowych” część materii organicznej jest przekształcana w ciekłe lub gazowe węglowodory, które mogą przemieszczać się w przestrzeń porową, wypierając wodę (rysunek 4c).

Ze wzrostem procesu kompakcji ziarna mineralne mają tendencję do układania się horyzontalnie, a materia organiczna w subhoryzontalne lamele. Na podstawie obserwacji szlifów stwierdzono, że materia organiczna (głównie kerogen) zachowuje się plastycznie [22]. Materia organiczna jest początkowo deponowana z ziarnami szkieletu i nie wypełnia porów; ze wzrostem dojrzałości kerogen staje się mobilny i może być wyciskany w przestrzeń porową.

Założone przy modelowaniu parametry szkieletu oraz objętości składników mineralnych podano w tablicy 3 .

Badania laboratoryjne [30] wykazują, że wartości modułu $K$ dla kerogenu zawierają się między 3,5 GPa a 5,0 GPa dla utworów Green River. Analizując zachowanie się wartości $K / M I$ dla próbek piaskowców i skał węglanowych w warunkach całkowitego nasycenia i ,suchych” (dry) w funkcji porowatości, uzyskali oni zależności przedstawione na rysunku 5 a i 5b. Przy porowatości równej zero można odczytać stosunek $K_{m a} / M I_{m a}=0,9$ (w szkielecie) dla piaskowców i 2,1 dla wapieni. Podobne krzywe (rysunek 5c) opracowano dla próbek kerogenu. Zachowują się one analogicznie jak w przypadku próbek węglanowych. Wartość $K_{m a} / M I_{m a}$ wynosi około 2,0, a więc można przyjąć, że $M I_{m a}$ jest równe połowie $K_{m a}$.

Obliczając parametry sprężyste dla syntetycznych modeli łupków ilastych, założono następujące rozmieszczenia poszczególnych składników budujących szkielet oraz fazy występujące $\mathrm{w}$ przestrzeni porowej (rysunek 6).

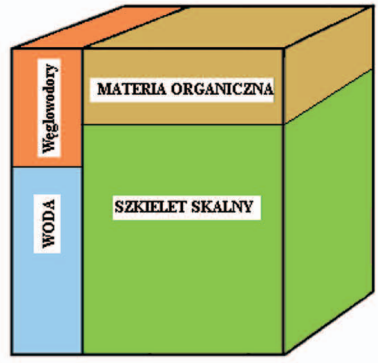

c

Rys. 4. Modele skał: a) skały bez materii organicznej; b) „niedojrzałe” skały z materią organiczną; c) „dojrzałe” skały z materią organiczną (na podstawie [22], zmodyfikowane przez [4])

Tablica 3. Parametry dla syntetycznego modelu łupków z kerogenem

\begin{tabular}{|c|c|c|c|c|c|c|c|c|}
\hline $\begin{array}{l}\text { Minerał/ } \\
\text { medium }\end{array}$ & $K_{m a}[\mathrm{GPa}]$ & $\begin{array}{c}M I_{m a} \\
{[\mathrm{GPa}]}\end{array}$ & $\begin{array}{l}\mathrm{RHOB}_{m a} \\
{\left[\mathrm{~g} / \mathrm{cm}^{3}\right]}\end{array}$ & $\begin{array}{c}V_{P m a} \\
{[\mathrm{~km} / \mathrm{s}]}\end{array}$ & $\begin{array}{c}V_{\text {Sma }} \\
{[\mathrm{km} / \mathrm{s}]}\end{array}$ & $\begin{array}{c}\text { Objętość } V \\
{[\%]}\end{array}$ & Położenie & Opis \\
\hline Kwarc & 35,45 & 39,81 & 2,65 & 5,780 & 3,876 & 15 do 30 & szkielet & [9] \\
\hline Kalcyt & 67,00 & 28,10 & 2,71 & 6,209 & 3,220 & 3 lub 0,0 & szkielet & {$[11]$} \\
\hline Skalenie (albit) & 56,27 & 33,58 & 2,62 & 6,210 & 3,580 & 1,5 lub 0,0 & szkielet & {$[11]$} \\
\hline Piryt & 139,96 & 123,00 & 4,92 & 7,860 & 5,000 & 0,5 lub 0,0 & szkielet & {$[11]$} \\
\hline If & $\begin{array}{l}26,00 \\
16,83\end{array}$ & $\begin{array}{r}14,00 \\
7,03\end{array}$ & $\begin{array}{l}2,65 \\
2,60\end{array}$ & $\begin{array}{l}4,110 \\
3,175\end{array}$ & $\begin{array}{l}2,300 \\
1,644\end{array}$ & $70 \div 85$ & szkielet & $\begin{array}{c}\text { illit/smektyt } \\
\text { osady wenloku } \\
{[3]}\end{array}$ \\
\hline Kerogen & $\begin{array}{l}5,53 \\
2,90 \\
\end{array}$ & $\begin{array}{l}3,20 \\
2,70\end{array}$ & $\begin{array}{l}1,25 \\
1,30\end{array}$ & 2,800 & 1,600 & $0,0 \div 10$ & $\begin{array}{c}\text { szkielet lub } \\
\text { pory } \alpha=0,05\end{array}$ & {$[28]$} \\
\hline Woda (solanka) & 2,60 & 0,00 & 1,05 & 1,540 & & $80 \div 100$ & $\begin{array}{c}\text { w porach } \\
\alpha=0,05,0,1\end{array}$ & woda $\mathrm{z}$ gazem \\
\hline Gaz & 0,05 & 0,00 & 0,10 & & & $0 \div 20$ & $\begin{array}{c}\text { w porach } \\
\alpha=0,05,0,1\end{array}$ & \\
\hline
\end{tabular}


a)

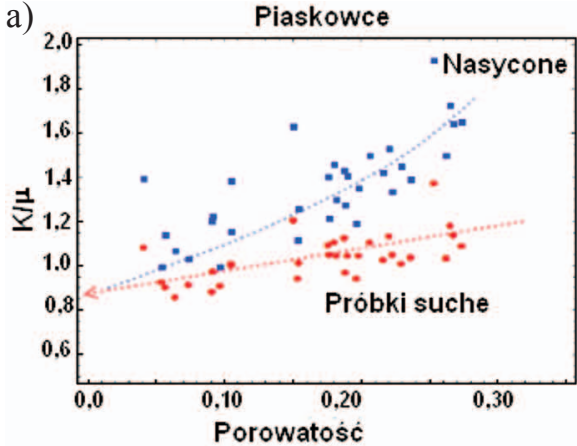

b)

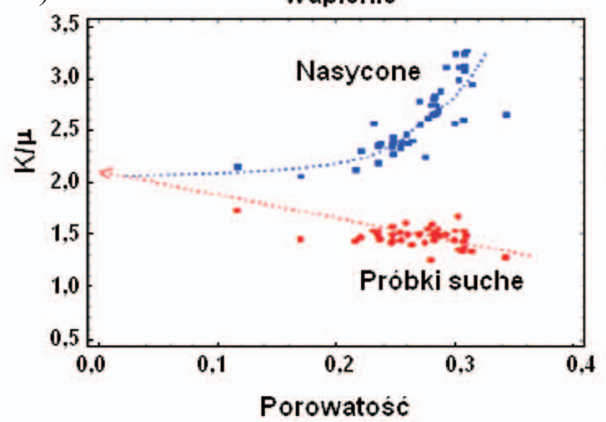

c)

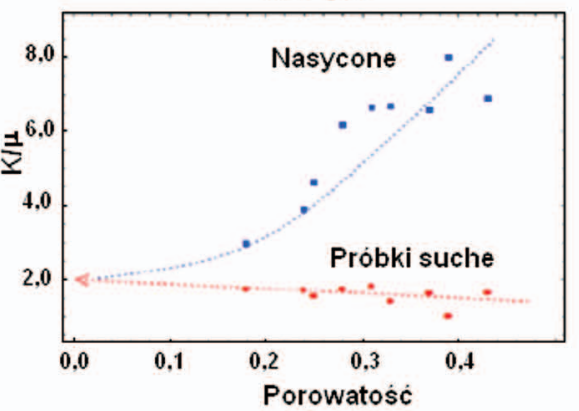

Rys. 5. a) Zależność między $K / \mu$ i porowatością dla piaskowców, dane na podstawie Han [13], b) Zależność między $K / \mu$

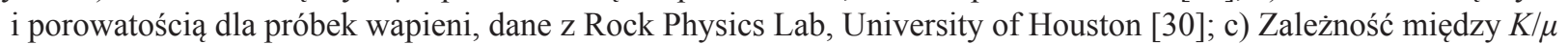
i porowatością dla próbek kerogenu z Basenu Green River [30]

a)

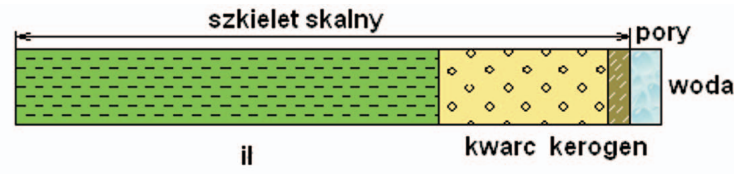

b)

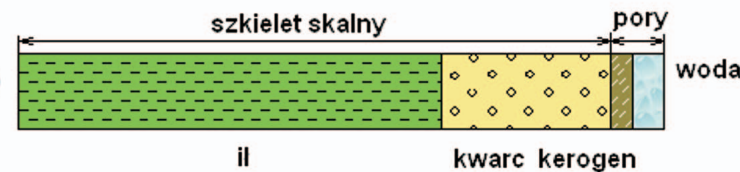

c)

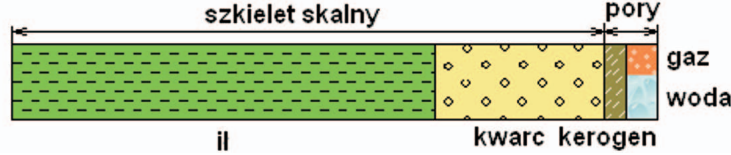

Rys. 6. Modele przyjęte w obliczeniach: a) szkielet zawiera ił, kwarc i kerogen, w porach woda, b) kerogen i woda w przestrzeni porowej, c) kerogen, woda i gaz w porach

Model 1 zakładał (rysunek 6a):

- obecność składników mineralnych w szkielecie łącznie $\mathrm{z}$ kerogenem, nie brano pod uwagę niewielkich domieszek węglanowych, skaleni czy pirytu;

- spektrum porowe: $\alpha_{\text {wody }}=0,05$ i $C\left(\alpha_{\text {wody }}\right)=\Phi=0,05$;

- pory nasycone wodą złożową, parametry przyjęte dla wody: $K_{W}=2,6 \mathrm{GPa}, R H O B_{W}=1,05 \mathrm{~g} / \mathrm{cm}^{3}$.

Wyniki obliczeń przedstawione na rysunku 7 pokazują zmiany prędkości $V_{P}$ w zależności od objętości kerogenu. W pierwszym modelu założono obecność kerogenu w szkielecie, obok kwarcu i materiału ilastego, oraz przestrzeń porową nasyconą całkowicie wodą złożową przy porowatości 5\%. Widać niewielki wzrost $V_{P}$ ze wzrostem objętości kerogenu.

Model drugi (rysunek 6b) zakłada obecność kerogenu w porach, tym samym zmieniają się wartości modułów dla szkieletu $K_{m a}$ i $M I_{m a}$ oraz gęstości $R H O B_{m a}$. Spektrum przestrzeni zajętej przez kerogen: $\alpha_{\text {kerog }}$ i $C\left(\alpha_{\text {kerog }}\right)$.

Jest rzeczą oczywistą, że wzrastająca objętość kwarcu w szkielecie skalnym pociąga za sobą wzrost takich parametrów jak: moduły odkształcenia objętości $K$ i postaci $M I$, prędkości fali podłużnej $V_{P}$ i poprzecznej $V_{S}$ oraz gęstość objętościowa $R H O B$.
Wykonano również dodatkowe obliczenia parametrów sprężystych dla różnych współczynników kształtu, który zajmuje kerogen, ale o identycznych parametrach dla szkieletu i wody w porach. Na rysunku 7 i 8 zaznaczono te krzywe dla $\alpha_{\text {kerog }}=0,001$ i 0,5 oraz różnych objętości kerogenu $\left(V_{\text {kerog }}\right.$ od 0 do 0,1$)$. Zmiany prędkości fali P są bardzo niewielkie od $0,1 \%$ do $3 \%$, a stosunku $V_{P} / V_{S}$ nieistotne.

Na rysunku 9 i 10 przedstawiono wykresy zależności modułów odkształcenia objętości $K$ i postaci $M I$ w funkcji objętościowej zawartości kerogenu. Moduły zachowują się bardzo podobnie jak prędkość fali P, liniowo maleją ze wzrostem objętości kerogenu.

Wykonano również obliczenia dla modelu zawierającego kwarc, kalcyt, skalenie, ił i kerogen oraz dodatkowo domieszki pirytu. Analizując wyniki obliczeń, można zauważyć, że obecność dodatkowych składników w szkielecie skalnym powoduje wzrost modułów $K, M I$ oraz gęstości objętościowej $R H O B$, nie wpływa jednak na sam charakter zmian parametrów sprężystych ze zmianą objętości kerogenu.

Obliczenia wykonano także dla przypadku, gdy w porach występuje woda i gaz.

Początkowo założono, że woda i gaz występują w oddzielnych porach, o takim samym spektrum porowym: $\alpha_{\text {wody }}=0,05$ i $C\left(\alpha_{w o d y}\right)=\Phi=0,05$ oraz $\alpha_{g a z}=0,05$ i $C\left(\alpha_{g a z}\right)=\Phi=0,05$, co w sumie dawało porowatość $\Phi=0,1$.

W następnym modelu założono, że woda i gaz stanowią mieszaninę, a parametry $K_{f}$ obliczono dla nasycenia gazem $S_{g}=V_{g}=0,2$ ze wzoru znanego jako wzór Wooda [19]:

$$
\frac{1}{K_{f}}=\frac{V_{w}}{K_{w}}+\frac{V_{g}}{K_{g}}
$$

Przy parametrach gazu $K_{g}=0,05 \mathrm{GPa}$ i $R H O B_{g}=0,03 \mathrm{~g} / \mathrm{cm}^{3}$ otrzymano wartość $K_{f}=0,23 \mathrm{GPa}$, a z liniowej zależności gęstość objętościową mieszaniny $R H O B_{f}=0,9 \mathrm{~g} / \mathrm{cm}^{3}$. Wyniki obliczonych parametrów dla modelu A - gdy woda i gaz zajmują oddzielne pory, i modelu B - w którym woda i gaz mieszają się, zestawiono w tablicy 4 . 

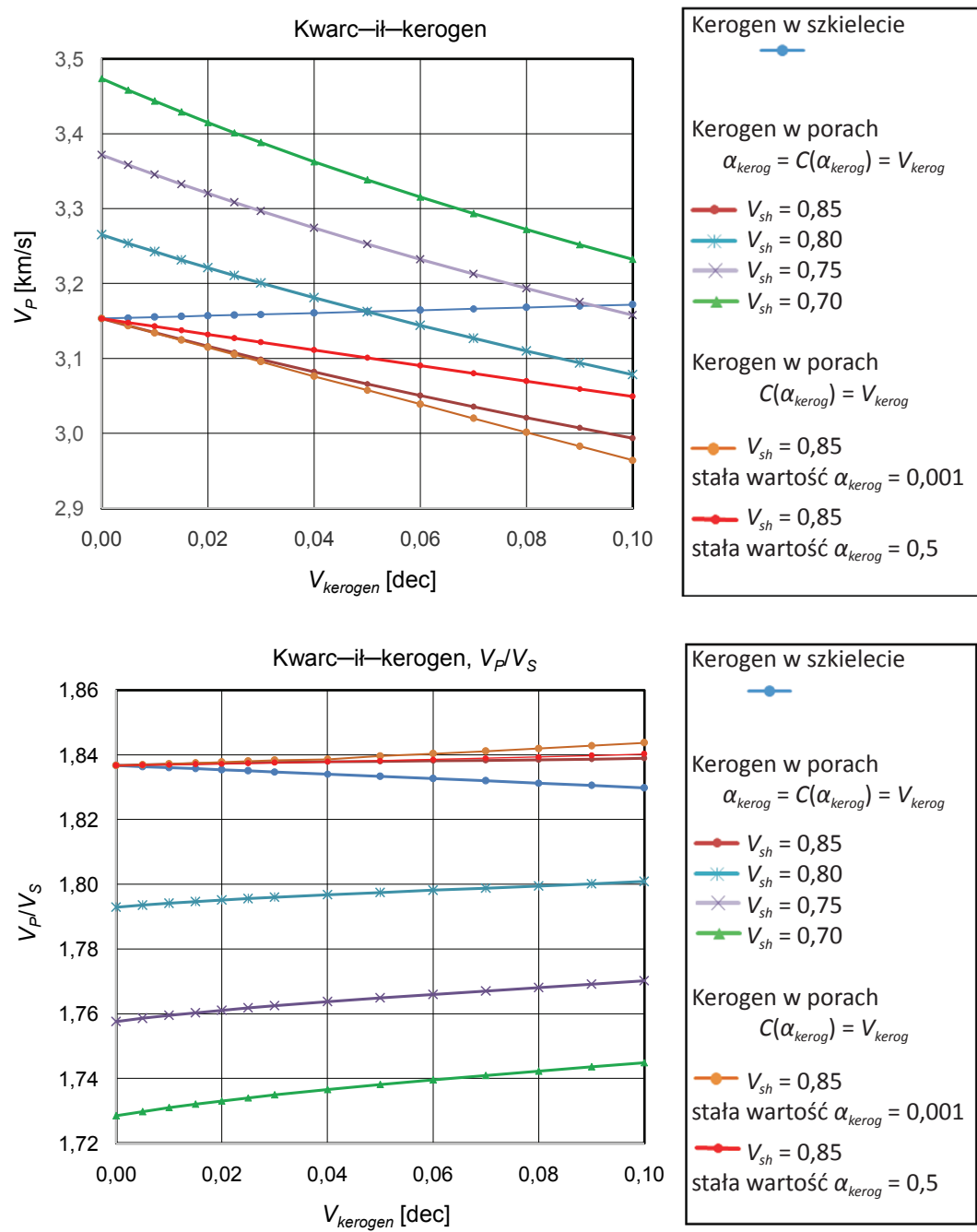

Rys. 7. Wykres zależności $V_{P}$ od objętości kerogenu $\left(V_{\text {kerogen }}\right)$. Model z kerogenem w szkielecie lub w porach. Spektrum kerogenu $\alpha_{\text {kerog }}=C\left(\alpha_{\text {kerog }}\right)=V_{\text {kerog }}$. Dwie ostatnie krzywe (jasnobrązowa i czerwona) obliczone dla $V_{s h}=0,85$ oraz dla $\alpha_{\text {kerog }}=0,001$ i 0,5 przy różnych objętościach kerogenu od 0 do 0,1
Rys. 8. Wykres zależności stosunku $V_{P} / V_{S}$ od objętości kerogenu $\left(V_{\text {kerogen }}\right)$. Model z kerogenem w szkielecie lub w porach a)

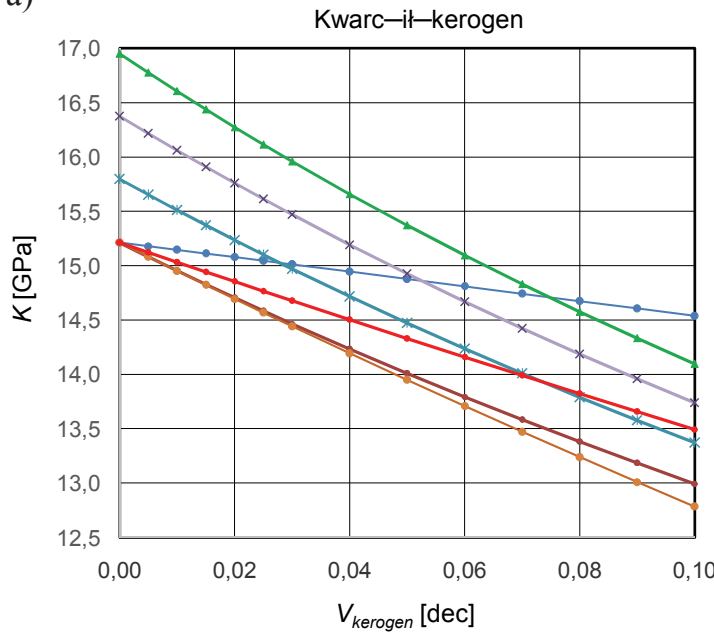

b)

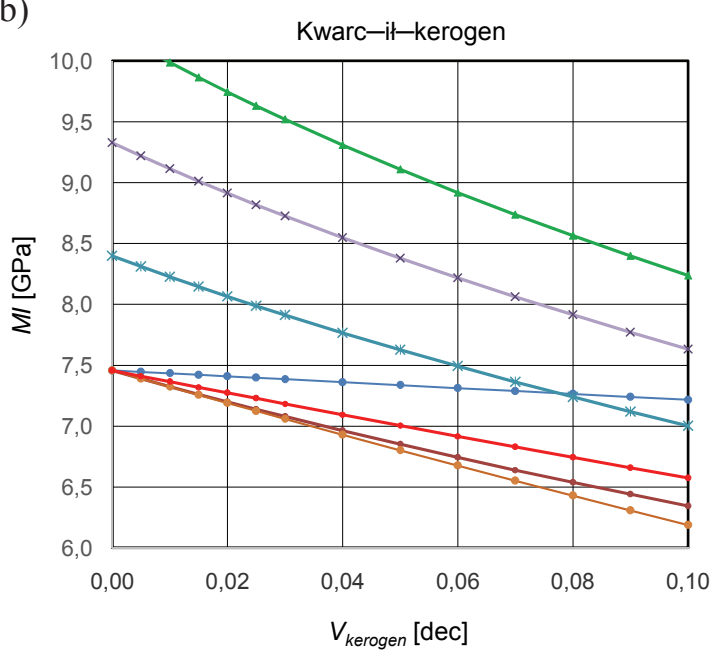

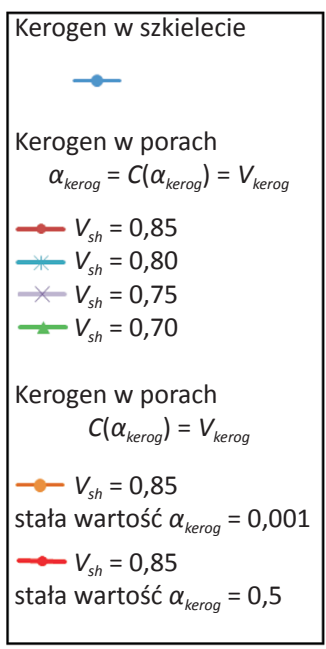

Rys. 9. a) moduł odkształcenia objętości $K$ w funkcji objętościowej zawartości kerogenu; b) moduł odkształcenia postaci $M I$ w funkcji objętościowej zawartości kerogenu. Modele z kerogenem w szkielecie lub w porach

Analizując wyniki przedstawione w tablicy 4 i na rysunku 10, można zauważyć, że prędkości $V_{P}$ i $V_{S}$ oraz impedancje akustyczne AIP i AIS ze wzrostem objętości kerogenu są nieco większe dla modelu, gdy woda i gaz mieszają się wzajemnie.

\section{Graniczne wartości modułów sprężystości}

W odniesieniu do wartości modułów sprężystości opisujących ośrodki dwu- i więcej fazowe zostały wprowadzone granice, które w literaturze znane są jako granice (lub uśrednienie) Hashina i Shtrikmana, granice Voigta oraz Reussa (lub Wooda). 
Tablica 4. Wyniki obliczonych parametrów dla modelu A - szkielet: kwarc, ił, $V_{s h}=0,85$, kerogen w porach, gaz i woda w oddzielnych porach i modelu B - szkielet: kwarc, ił, $V_{s h}=0,85$, kerogen w porach, gaz i woda mieszają się, $V g=0,2$

\begin{tabular}{|c|c|c|c|c|c|c|c|c|c|c|}
\hline \multicolumn{5}{|c|}{ Model A: woda i gaz w oddzielnych porach } & & \multicolumn{5}{|c|}{ Model B: woda i gaz mieszają się } \\
\hline $\begin{array}{c}V_{P} \\
{[\mathrm{~km} / \mathrm{s}]}\end{array}$ & $\begin{array}{c}V_{S} \\
{[\mathrm{~km} / \mathrm{s}]}\end{array}$ & $\begin{array}{l}\text { RHOB } \\
{\left[\mathrm{g} / \mathrm{cm}^{3}\right]}\end{array}$ & $\begin{array}{c}A I P \\
\mathrm{~km} / \mathrm{s} \cdot \mathrm{g} / \mathrm{cm}^{3}\end{array}$ & $\begin{array}{c}\text { AIS } \\
\mathrm{km} / \mathrm{s} \cdot \mathrm{g} / \mathrm{cm}^{3}\end{array}$ & $V_{\text {kerog }}$ & $\begin{array}{c}V_{P} \\
{[\mathrm{~km} / \mathrm{s}]}\end{array}$ & $\begin{array}{c}V_{S} \\
{[\mathrm{~km} / \mathrm{s}]}\end{array}$ & $\begin{array}{l}\text { RHOB } \\
\mathrm{g} / \mathrm{cm}^{3}\end{array}$ & $\begin{array}{c}A I P \\
\mathrm{~km} / \mathrm{s} \cdot \mathrm{g} / \mathrm{cm}^{3}\end{array}$ & $\begin{array}{c}A I S \\
\mathrm{~km} / \mathrm{s} \cdot \mathrm{g} / \mathrm{cm}^{3}\end{array}$ \\
\hline 1,944 & 1,228 & 2,414 & 4,694 & 2,964 & 0,000 & 2,558 & 1,626 & 2,522 & 6,451 & 4,101 \\
\hline 1,935 & 1,222 & 2,407 & 4,658 & 2,942 & 0,005 & 2,549 & 1,621 & 2,515 & 6,412 & 4,076 \\
\hline 1,926 & 1,216 & 2,401 & 4,623 & 2,920 & 0,010 & 2,541 & 1,615 & 2,509 & 6,373 & 4,052 \\
\hline 1,917 & 1,211 & 2,394 & 4,588 & 2,899 & 0,015 & 2,532 & 1,610 & 2,502 & 6,335 & 4,028 \\
\hline 1,908 & 1,205 & 2,387 & 4,554 & 2,878 & 0,020 & 2,524 & 1,605 & 2,495 & 6,297 & 4,005 \\
\hline 1,899 & 1,200 & 2,380 & 4,694 & 2,964 & 0,025 & 2,516 & 1,600 & 2,488 & 6,260 & 3,982 \\
\hline 1,890 & 1,195 & 2,374 & 4,658 & 2,942 & 0,030 & 2,508 & 1,596 & 2,481 & 6,223 & 3,960 \\
\hline 1,873 & 1,185 & 2,360 & 4,623 & 2,920 & 0,040 & 2,492 & 1,586 & 2,468 & 6,150 & 3,915 \\
\hline 1,856 & 1,175 & 2,346 & 4,355 & 2,757 & 0,050 & 2,477 & 1,578 & 2,454 & 6,080 & 3,872 \\
\hline 1,840 & 1,165 & 2,333 & 4,291 & 2,719 & 0,060 & 2,463 & 1,569 & 2,441 & 6,010 & 3,829 \\
\hline 1,823 & 1,156 & 2,319 & 4,229 & 2,681 & 0,070 & 2,448 & 1,561 & 2,427 & 5,943 & 3,788 \\
\hline 1,808 & 1,147 & 2,306 & 4,167 & 2,644 & 0,080 & 2,435 & 1,553 & 2,414 & 5,876 & 3,747 \\
\hline 1,792 & 1,138 & 2,292 & 4,107 & 2,608 & 0,090 & 2,421 & 1,545 & 2,400 & 5,811 & 3,708 \\
\hline 1,776 & 1,129 & 2,279 & 4,048 & 2,572 & 0,100 & 2,408 & 1,537 & 2,386 & 5,747 & 3,668 \\
\hline
\end{tabular}

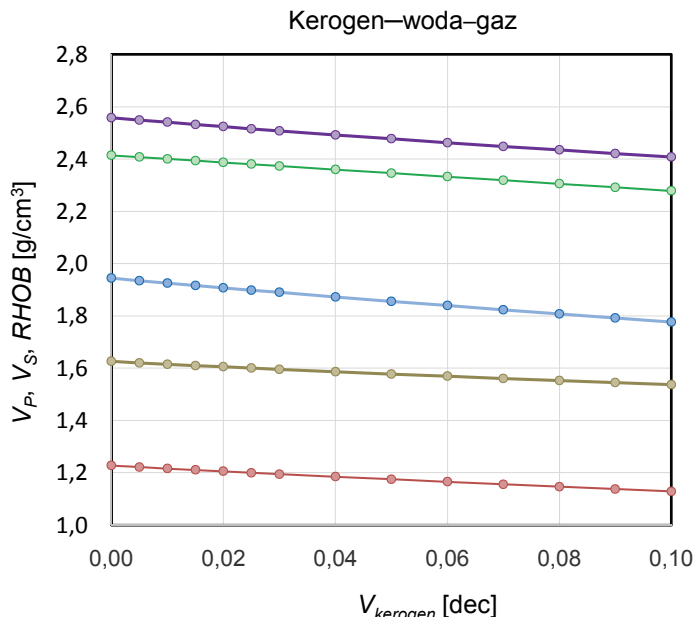

Woda i gaz w oddzielnych porach

$\because V_{p} \nrightarrow V_{s} \nrightarrow R H O B \quad \multimap V_{p} \quad \multimap V_{s}$

Rys. 10. Wykres $V_{P}, V_{S}$ i $R H O B$ w funkcji objętościowej zawartości kerogenu. Kerogen znajduje się w porach, woda i gaz wypełniają oddzielne pory lub mieszają się wzajemnie, dając jednorodne medium

\section{a) Granice Hashina i Shtrikmana}

Hashin i Shtrikman [19] wprowadzili graniczne wartości dla modułów opisujących ośrodki efektywne zawierające dwie fazy (składniki) lub więcej.

Znając objętościowe zawartości tych składników $\left(f_{1}, f_{2}\right)$ i ich moduły $\left(K_{1}, K_{2}, \mu_{1}, \mu_{2}\right)$, można napisać:

$$
\begin{aligned}
K_{1}+\frac{f_{2}}{\frac{1}{K_{2}-K_{1}}+\frac{f_{1}}{K_{1}+\frac{4}{3} \mu_{1}}} \leq K_{e f} & \leq \\
& \leq K_{2}+\frac{f_{1}}{\frac{1}{K_{1}-K_{2}}+\frac{f_{2}}{K_{2}+\frac{4}{3} \mu_{2}}}
\end{aligned}
$$

oraz

$$
\begin{array}{r}
\mu_{1}+\frac{f_{2}}{\frac{1}{\mu_{2}-\mu_{1}}+\frac{2 \cdot f_{1}\left(K_{1}+2 \mu_{1}\right)}{5 \mu_{1}\left(K_{1}+\frac{4}{3} \mu_{1}\right)}} \leq \mu_{e f} \leq \\
\leq \mu_{2}+\frac{f_{1}}{\frac{1}{\mu_{2}-\mu_{1}}+\frac{2 \cdot f_{2}\left(K_{2}+2 \mu_{2}\right)}{5 \mu_{1}\left(K_{2}+\frac{4}{3} \mu_{2}\right)}}
\end{array}
$$

Obliczone moduły efektywne zawierają się pomiędzy dolną (z lewej strony) i górną (z prawej) granicą.

\section{b) Granice Voigta i Reussa (lub Wooda)}

Uproszczone wzory na graniczne wartości modułów przedstawione zostały przez Voigta i Reussa (ta ostatnia znana jest również jako granica Wooda) [19].

Górną granicę określoną przez Voigta dla dowolnych modułów sprężystości efektywnego ośrodka skalnego (np. $K_{V}$ 
i $\mu_{V}$, również dla $E_{V}$ ) złożonego z kilku składników ( $i=1$, $\ldots, N)$ można przedstawić jako:

$$
K_{V}=\sum_{i=1}^{N} f_{i} \cdot K_{i} \text { oraz } \mu_{V}=\sum_{i=1}^{N} f_{i} \cdot \mu_{i}
$$

Granica ta przedstawia stosunek średnich wartości naprężeń do średnich wartości odkształceń, gdy wszystkie komponenty skalne są odniesione do tego samego odkształcenia (isostrain).

Dolna granica określona przez Reussa (opisana również przez Wooda) dla modułów efektywnego ośrodka $K_{R}$ i $\mu_{R}$ jest opisana wzorami:

$$
\frac{1}{K_{R}}=\sum_{i=1}^{N} \frac{f_{i}}{K_{i}} \quad \text { i } \frac{1}{\mu_{R}}=\sum_{i=1}^{N} \frac{f_{i}}{\mu_{i}}
$$

Granica ta prezentuje stosunek średnich wartości naprężeń do średnich wartości odkształceń, gdy wszystkie komponenty skalne odpowiadają tym samym naprężeniom (isostress).

Wzory są słuszne przy założeniu, że każda składowa występująca w ośrodku jest izotropowa i doskonale sprężysta. Gdy jedna ze składowych jest cieczą lub gazem, dla której moduł odkształcenia postaci $\mu=0$, uśrednienie Reussa daje takie same wartości jak dolna granica Hashina-Shtrikmana (jest to przypadek zawiesiny ziaren w cieczy porowej).

Wzór podawany przez Wooda odnosi się również do dwóch składników cieczy porowych (np. woda i gaz lub woda i ropa) (np. [2]).

Górna i dolna granica dla modułów sprężystości utożsamiana jest $\mathrm{z}$ modelami skał zbitych (model stiff) lub niescementowanych (model soft), które w różny sposób opisują związki modułów sprężystości w funkcji porowatości skały.

Dla tego samego zakresu porowatości w osadach scementowanych (zbitych) obserwuje się prędkości znacznie wyższe niż w przypadku osadów luźnych. Różnicę tę opisują dwa modele, nazywane modelami stiff sand (zbite piaski) i soft sand (luźne piaski). W każdym modelu prędkość nadal zależy od porowatości i zailenia. Dla tej samej porowatości większemu zaileniu odpowiada mniejsza prędkość. W przypadku skał zbitych charakterystyczny jest szybki i niemal liniowy spadek prędkości wraz ze wzrostem porowatości. W modelu skał luźnych (soft) najsilniejsze obniżenie prędkości obserwuje się dla małych porowatości $(0 \div 10 \%)$.

Na rysunku 11 przedstawiono wykres zależności prędkości fali $\mathrm{P}$ w funkcji porowatości z zaznaczonymi granicami Voigta (górną) i Reussa (dolną), obliczonymi dla modelu piaskowiec-woda, jak również granica Reussa (dolną) dla modelu ił-woda. Oznaczono także krzywe obliczone na podstawie relacji Wyllie i Raymera-Hunta-Gardnera (RHG). Na wykres naniesione zostały punkty odpowiadające utworom ilastym syluru i ordowiku z otworu Lub-1 (basen bałtycki) oraz piaskowcowo-ilastym miocenu z otworu Ch D-3 (zapadlisko przedkarpackie). Dla porównania zaznaczono punkty charakteryzujące utwory luźne (zawiesina), zaczerpnięte $\mathrm{z}$ pracy [12].

Analizując powyższy rysunek, można zauważyć, że osady syluru i ordowiku, leżące w górnym rogu, obwiedzione elipsą, charakteryzują utwory znajdujące się pod znacznym ciśnieniem. Próbki piaskowców i piaskowcowo-ilaste miocenu zajmują położenie powyżej granicy Reussa i wykazują zróżnicowany wpływ diagenezy i kompakcji lub słabe scementowanie, natomiast próbki osadów morskich, nieskonsolidowanych leżą na dolnej granicy Reussa i odpowiadają zawiesinie (suspension). Zaznaczono również graniczną wartość porowatości $\Phi c=0,39$, oddzielającą osady piaskowcowo-ilaste od zawiesiny.

Przeanalizowany został również charakter zmienności prędkości obu fal $V_{S}=f\left(V_{P}\right)$ (z lewej, rysunek 12)

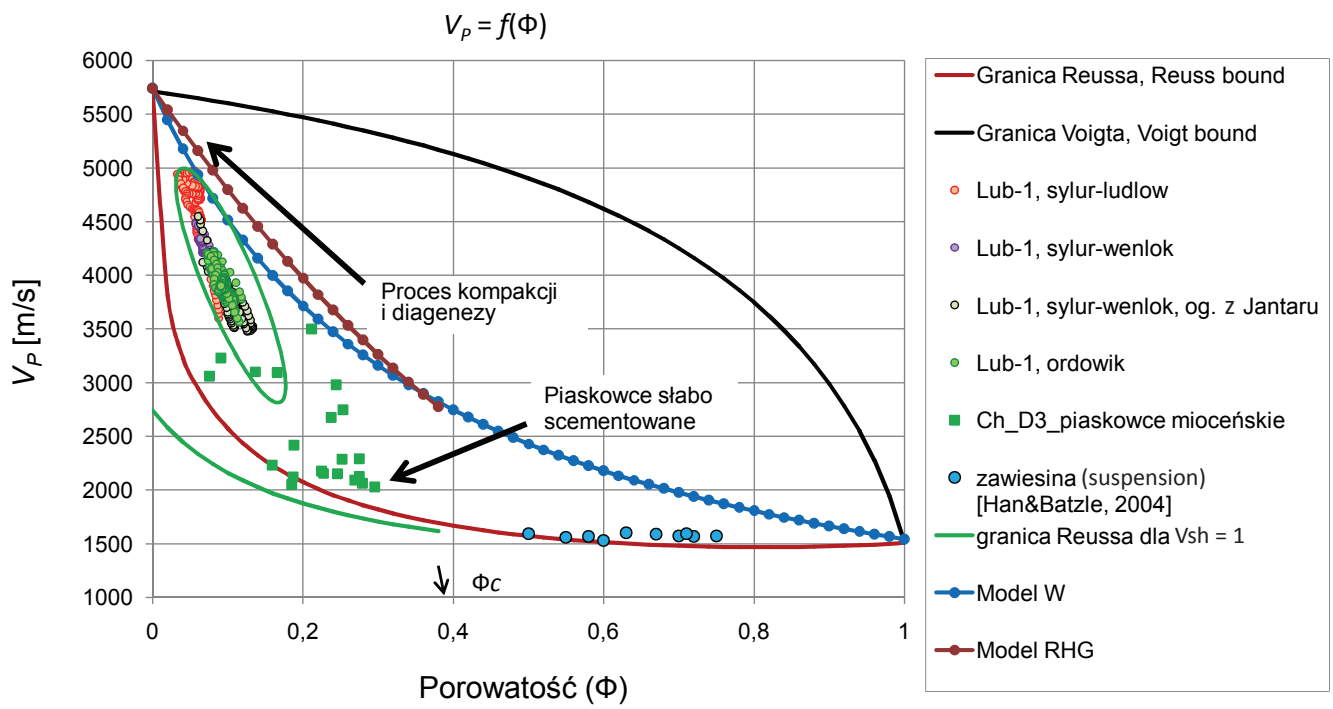

Rys. 11. Zależność $V_{P}=f(\Phi)$ z zaznaczonymi granicami Voigta (górna) i Reussa (dolna). Na wykres naniesiono punkty odpowiadające utworom ilastym syluru i ordowiku z otworu Lub-1 oraz piaskowcowo-ilastym miocenu z otworu ChD-3. Dla porównania zaznaczono punkty charakteryzujące utwory luźne (zawiesina) [12] 
i impedancji akustycznej AIS $=\mathrm{f}($ AIP) $(z$ prawej). Punkty naniesione na wykres odpowiadają interwałom gazonośnym, wodonośnym i nasyconym wodą z gazem dla utworów syluru i ordowiku z otworu Lub-1. Wyraźnie zaznaczają się warstwy o różnym nasyceniu gazem (kolor żółty i czerwony - duże nasycenie gazem) oraz nasyceniu wodą (kolor niebieski).

Podobny rozkład punktów otrzymano dla mioceńskich utworów piaskowcowo-ilastych nasyconych w różnych proporcjach wodą lub gazem [7].
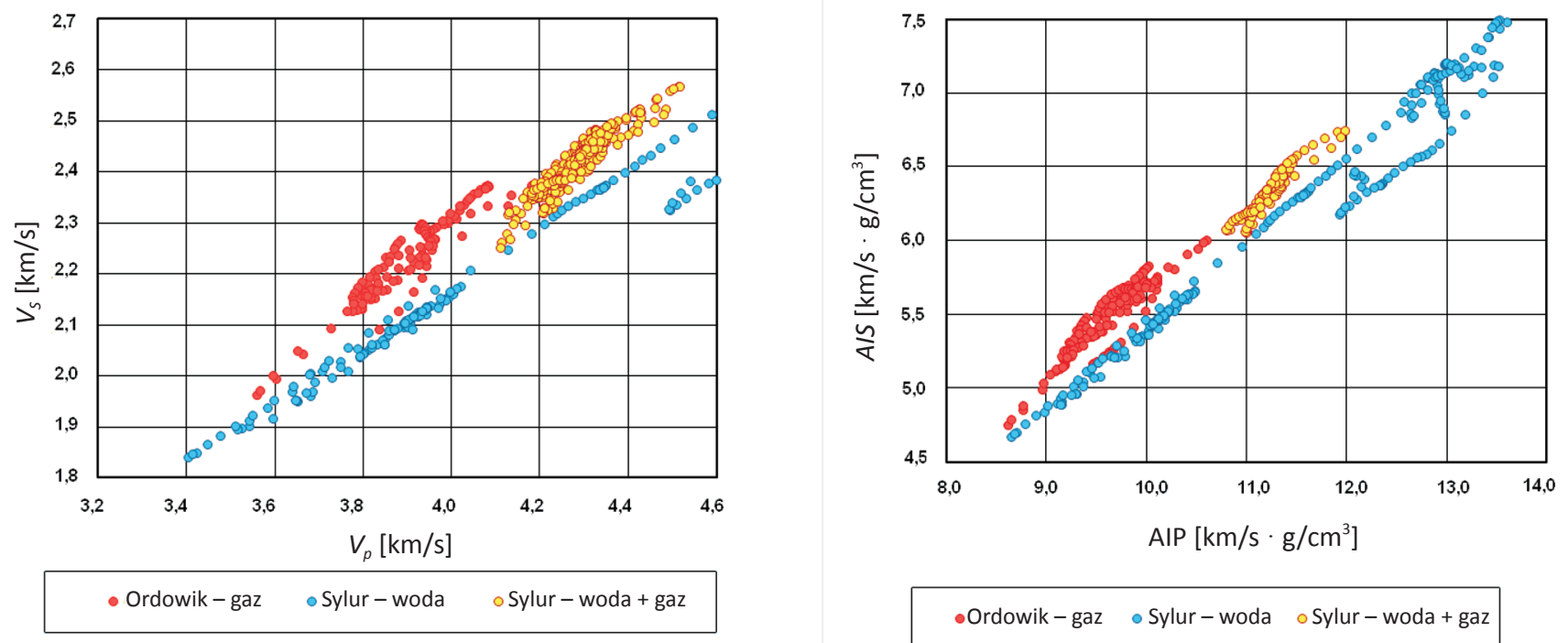

-Ordowik - gaz @ Sylur - woda oSylur - woda + gaz

Rys. 12. Zależność prędkości (z lewej) i impedancji akustycznych (z prawej) fal P i S dla wybranych interwałów z otworu Lub-1

\section{Podsumowanie i wnioski}

Wykonano modelowania parametrów sprężystych przy użyciu programu Estymacja TP i relacji teoretycznych Kustera-Toksöza oraz Biota-Gassmana.

Zestawiono zmiany $V_{P}$ w funkcji zawartości kerogenu. Założono modele odpowiadające utworom syluru i ordowi$\mathrm{ku}$, zawierającym kerogen w zakresie od $0 \%$ do $10 \%$.

Modele zawierały: kwarc, illit, kerogen w różnej objętości oraz wodę lub gaz w przestrzeni porowej. Obliczenia wykonano również dla przypadku obecności dodatkowych minerałów: kalcytu i pirytu.

Analizując uzyskane wyniki, można stwierdzić, że:

- kerogen ma wpływ na rejestrowane parametry, ale charakter tego wpływu zależy od zawartości iłów i geometrii przestrzeni porowej;

- zmiany parametrów sprężystych w miarę wzrostu objętości kerogenu są niewielkie, gdy kerogen występuje w szkielecie skalnym, nieco większe obserwuje się, gdy kerogen znajduje się w porach skalnych;

- obecność kerogenu w przestrzeni porowej obniża prędkości fal $\mathrm{P}, \mathrm{S}$ oraz modułów odkształcenia objętości $K$ i postaci $M I$;

- stosunek $V_{P} / V_{S}$ wykazuje wzrost wraz ze wzrostem objętości kerogenu;

- obecność gazu obniża parametry sprężyste, gęstość objętościową oraz $V_{P} / V_{S}$;

- obliczone prędkości fali P w otworze Lub-1 plasują się wewnątrz granic teoretycznych Voigta i Reussa (podobnie zachowują się moduły odkształcenia objętości $-K$ ); ich położenie wskazuje na znaczne ciśnienia, które panują na głębokościach występowania osadów;

- zestawienie prędkości fali podłużnej $\left(V_{P}\right)$ i poprzecznej $\left(V_{S}\right)$ oraz impedancji akustycznych (AIP, AIS) pozwala na odróżnienie utworów nasyconych wodą od nasyconych gazem.

\section{Podziękowania}

Prezentowane wyniki badań były finansowane częściowo w ramach zadania $10 \mathrm{w}$ projekcie MWSSSG Polskie Technologie dla Gazu Łupkowego, a częściowo w ramach projektu PolandSPAN.

Prosimy cytować jako: Nafta-Gaz 2015, nr 12, s. 1005-1016, DOI: 10.18668/NG2015.12.09

Artykuł nadesłano do Redakcji 4.08.2015 r. Zatwierdzono do druku 13.10.2015 r. 


\section{Literatura}

[1] Allan A. M., Vanorio T., Dahl J. E. P.: Pyrolysis-induced $P$-wave velocity anisotropy in organic-rich shales. Geophysics 2014, vol. 79, nr 2, s. D41-D53.

[2] Bala M.: Effect of water and gas saturation in layers on elastic parameters of rocks and reflection coefficients of waves. Acta Geophysica Polonica 1994, vol. 42, nr 2, s. 149-158.

[3] Bala M.: Effects of shale content, porosity and water- and gas-saturation in pores on elastic parameters of reservoir rocks based on theoretical models of porous media and welllogging data. Przegląd Geologiczny 2007, vol. 55, s. 46-53.

[4] Bala M.: Modelowanie parametrow sprezystych w lupkach ilastych przy wykorzystaniu teoretycznych relacji Kustera-Toksőza. Konferencja Naukowo-Techniczna Geopetrol 2014. Prace Naukowe Instytutu Nafty i Gazu 2014, nr 198.

[5] Bala M. (red.): Przygotowanie krzywych syntetycznych i pseudoakustycznych dla fali podluznej i krzywej pseudoakustycznej dla fali poprzecznej oraz syntetycznych krzywych gestosci objetosciowych i pseudogestosciowych dla otworow Darzlubie IG-1, Prabuty IG-1, Mielnik IG-1, Busowno IG-1 i Lopiennik $I G-1$. Towarzystwo Geosynoptyków, 2013, umowa $\mathrm{nr} 8 / \mathrm{U} / \mathrm{NB} / 2013$

[6] Bala M., Cichy A.: Metody obliczania predkosci fal P i S na podstawie modeli teoretycznych i danych geofizyki otworowej-program Estymacja. Monografia. Wydawnictwa AGH, 2006, 89 s.

[7] Bala M., Cichy A., Jarzyna J., Mortimer Z., Pietsch K., Puskarczyk E., Marzec P., Witek K., Niepsuj M., Zalewska J.: Modelowania teoretyczne i empiryczne wplywu zmiennego cisnienia i nasycenia gazem na parametry sprezyste, gestosc $i$ opornosc skal dla oceny przepuszczalnosci z danych geofizyki otworowej. Projekt badawczy nr NN525 363537, 2009-2012.

[8] Berryman J. G., Pride S. R., Wang H. F.: A differential scheme for elastic properties of rocks with dry or saturated cracks. Geophysics Journal International 2002, vol. 151, s. 597-611.

[9] Castagna J. P., Batzle M. L., Eastwood R. L.: Relationships between compressional wave and shear wave velocities in clastic silicate rocks. Geophysics 1985, vol. 50, nr 4, s. 571-581.

[10] Gasior I., Klaja J., Kowalska S., Przelaskowska A., Zalewska J.: Analiza rozkladu nasycenia woda przestrzeni porowej skal miocenskich na podstawie badan metoda NMR. Konferencja Naukowo-Techniczna Geopetrol 2004. Prace Naukowe Instytutu Nafty i Gazu 2004, nr 130.

[11] Halliburton: Log Interpretation Charts. 1991.

[12] Han D. H., Batzle M. L.: Gassmann's equation and fluid saturation effects on seismic velocities. Geophysics 2004, vol. 69, nr 2, s. 398-405.

[13] Han D. H., Nur A., Morgan D.: Effects of porosity and clay content on wave velocities in sandstones. Geophysics 1986 , vol. 51, nr 11, s. 2093-2107.

[14] Jones L. E. A., Wang H. F.: Ultrasonic velocities in Cretaceous shales from the Williston Basin. Geophysics 1981, vol. 46, nr 3, s. 288-297.

[15] Katahara K. W.: Clay mineral elastic properties. Presented at the 66th Annual International Meeting, Society Exploration Geophysics1996, s. 1691-1694.

[16] Kuila U., Prasad M., Kazemi H.: Assessing Knudsen flow in gas-flow models of shale reservoirs. CSEG Recorder 2013, vol. 38 , nr 5.

[17] Kuster G. T., Toksöz M. N.: Velocity and attenuation of seismic waves in two-phase media. Part I. Theoretical Formulations. Geophysics 1974, vol. 39, nr 5, s. 587-606.

[18] Matyasik I., Sloczynski T.: Niekonwencjonalne zloza gazushale gas. Nafta-Gaz 2010, nr 3, s. 159-172.

[19] Mavko G., Mukerji T., Dvorkin J.: The Rock Physics Handbook. Tools for seismic analysis in Porous media. Cambridge University Press, 2003.

[20] Modlinski Z. (red.): Darzlubie IG-1. Profile Głębokich Otworów Wiertniczych 2011, z. 128. Warszawa, Wydawnictwa PIG.

[21] Modlinski Z. (red.): Slupsk IG-1. Profile Głębokich Otworów Wiertniczych 2007, z. 116. Warszawa, Wydawnictwa PIG.

[22] Passey Q. R., Moretti F. J., Kulla J. B., Creaney S., Stroud J. D.: A Practical Model for Organic Richness from Porosity and Resistivity Logs. The American Association of Petroleum Geologists Bulletin 1990, vol. 74, nr 12, s. 1777-1794

[23] Poprawa P.: System weglowodorowy z gazem ziemnym w lupkach - polnocnoamerykanskie doswiadczenia i europejskie perspektywy. Przegląd Geologiczny 2010, vol. 58, nr 3, s. 216-225.

[24] Prasad M., Kopycinska M., Rabe U., Arnold W.: Measurement of Young's modulus of clay minerals using atomic force acoustic microscopy. Geophysical Research Letters 2002, vol. 29, $\mathrm{nr} 8$, s. 1172-1175.

[25] Srodon J., Kowalska S.: Ocena ilosciowa i jakosciowa skladu mineralnego skal miocenskich z otworow Jasionka-4 $i$ Chalupki Debnianskie-3. Konferencja Naukowo-Techniczna Geopetrol 2004. Prace Naukowe Instytutu Nafty i Gazu 2004, nr 130, s. 779-782.

[26] Such P.: Analiza wlasciwosci zbiornikowych i filtracyjnych rdzeni z otworow Chalupki Debnianskie-3 i Jasionka-4. Konferencja Naukowo-Techniczna Geopetrol 2004. Prace Naukowe Instytutu Nafty i Gazu 2004, nr 130, s. 793-796.

[27] Thomsen L.: Weak elastic anisotropy. Geophysics 1986 , vol. 51, nr 10, s. 1954-1966.

[28] Vernik L., Liu X.: Velocity anisotropy in shales: A petrophysical study. Geophysics 1997, vol. 62, nr 2, s. 521-532.

[29] Xu S., White R. E.: A new velocity model for clay-sand mixtures. Geophysical Prospecting 1995, vol. 43, nr 1, s. 91-118.

[30] Yan F., Han D. H.: Measurement of elastic properties of kerogen. SEG Houston 2013, Annual Meeting.

[31] Zhu F., Gibson R. L., Estil R.: A Critical Clay Content Model of Sand-Shale Mixtures from Log Data in the Gulf of Thailand. SEG 2001, Expanded Abstract 1-5.

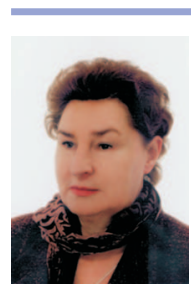

Prof. dr hab. inż. Maria BAŁA

Profesor nadzwyczajny.

Akademia Górniczo-Hutnicza im. Stanisława Staszica w Krakowie, Wydział Geologii, Geofizyki i Ochrony Środowiska, Katedra Geofizyki

al. Mickiewicza 30, 30-059 Kraków

E-mail:bala@geol.agh.edu.pl 